\title{
EFISIENSI PENGUNGKAPAN MODAL INTELEKTUAL DALAM PERUSAHAAN
}

\author{
Inanda Shinta Anugrahani ${ }^{1}$ \\ Email: inanda.shinta.fe@um.ac.id
}

\begin{abstract}
The business dynamics of the 21 st century have led to sudden changes. This sudden shift manifested itself as a shift from industry-based business to technology and knowledge. The purpose of this research is to understand various aspects that support the practice of intellectual capital disclosure, intellectual capital measurement methods, barriers and challenges to intellectual capital disclosure, as well as guidelines that can be used for intellectual capital disclosure. This research uses the library method. The type of information used in this research is secondary information sourced from previous literature. The results of the study indicate that the practice of disclosing intellectual capital is very important. This is because intellectual capital is important and relevant information that must be known by stakeholders. Intellectual capital is taken into account in the decision-making process, which can help companies manage assets more optimally. Basically, the guidelines regarding intellectual capital in Indonesia are implicitly stated in PSAK 19.
\end{abstract}

Keywords: Efficiency, Disclosure, Intellectual Capital

\section{PENDAHULUAN}

Kemajuan teknologi dan berkembangnya ilmu pengetahuan dalam dunia bisnis menuntut para pemilik bisnis agar dapat beradaptasi dengan perubahan. Pelaku usaha perlu untuk melakukan perubahan dalam menjalankan usaha guna memenangkan persaingan global. Chandra (2021) menyatakan bahwa pelaku bisnis dituntut untuk mampu menyesuaikan diri saat terjadi perubahan menjadi knowledge-based business dari labor-based business. Pada knowledge-based business, kemakmuran suatu perusahaan ditentukan oleh penciptaan transformasi dan kapitalisasi ilmu yang sebuah perusahaan miliki (Sawarjuwono dan Kadir 2003). Knowledge-based business berfokus dalam meningkatkan potensi perusahaan tidak hanya berasal dari kekayaan fisik, melainkan juga kekayaan tidak berwujud yang mampu menciptakan nilai tambah dalam meningkatkan nilai perusahaan.

Dalam menciptakan iklim persaingan yang kondusif, perusahaan harus memiliki keunggulan kompetitif agar mampu bertahan dalam jangka panjang serta mampu memenangkan kompetisi di era globalisasi saat ini. Nuryaman (2015) menyatakan bahwa modal intelektual merupakan salah satu keunggulan kompetitif perusahaan.

\footnotetext{
${ }^{1}$ Corresponding author: Universitas Negeri Malang, Jl. Semarang No.5, Sumbersari, Kec. Lowokwaru,
} Malang, Jawa Timur, 65145 
Modal intelektual merupakan bentuk kekayaan yang diciptakan dengan mengembangkan dan mengelola pengetahuan serta aset tidak berwujud (Garanina dan Dumay 2017). Fokus utama perusahaan dalam meningkatkan keunggulan kompetitif bukan terletak pada besarnya jumlah tenaga kerja melainkan pada nilai tambah yang diperoleh dari berbagai hal yang tidak mempunyai wujud fisik. Perubahan tersebut menuntut perusahaan untuk mengelola dan mengungkap aset tidak berwujud seperti modal intelektual untuk menciptakan keunggulan kompetitif dan meningkatkan nilai perusahaan (Secundo et al. 2017). Modal intelektual yang dapat meningkatkan keunggulan perusahaan diantaranya adalah pengetahuan yang dimiliki oleh tenaga kerja, nilai-nilai serta budaya yang tertanam pada perusahaan, dan hubungan yang dimiliki oleh perusahaan dengan pihak eksternal. Pengungkapan modal intelektual yang semakin baik dijalankan suatu bisnis maka kemampuan instansi dalam menciptakan citra yang baik akan semakin tinggi, sehingga keberlanjutan perusahaan dapat terjaga (Festa et al. 2021).

Dinamika bisnis pada abad ke-21 mengakibatkan pergeseran dari bisnis dengan basis industrial menjadi bisnis dengan basis pengetahuan serta teknologi. Pergeseran dalam dunia bisnis ini juga disebut sudden shift. Selama empat dekade terakhir, pemanfaatan aset tidak berwujud telah menggeser kepemilikan aset berwujud perusahaan (Lestari dan Suryani 2020). Perubahan yang terjadi saat ini dikendalikan oleh elemen intelektual sehingga modal konvensial menjadi kurang penting (Singh dan Mitchell Van der Zahn 2008). Modal konvensional yang berwujud fisik menjadi tidak diperhatikan jika dibandingkan dengan aset dengan basis ilmu serta teknologi. Hal tersebut menunjukkan bahwa eksistensi instansi dewasa ini dipengaruhi oleh ilmu serta teknologi yang dimiliki, bukan modal konvensional (Oktavianti et al. 2014). Teknologi dan pengetahuan yang dimiliki perusahaan sebagai modal intelektual menjadi jantung pertumbuhan bagi organisasi bisnis.

Modal intelektual menjadi contoh metode yang dimanfaatkan pada peninjauan aset ilmu yang dimiliki perusahaan (Guthrie dan Petty 2000). Konsep modal intelektual menjadi tantangan bagi akuntan dalam menentukan cara pengungkapan modal intelektual pada laporan keuangan perusahaan (Sawarjuwono dan Kadir 2003). Modal intelektual merupakan aspek penting yang dapat melengkapi informasi pada laporan keuangan sebagai dasar dalam pengambilan keputusan. Walaupun demikian, modal intektual masih bersifat sukarela karena belum adanya aturan pasti dan mengikat bagi perusahaan untuk melaporkannya.

PSAK No. 19 menjabarkan tentang aset tak berbentuk sebagai aset non-moneter yang bisa dikenali namun tidak memiliki bentuk nyata. Aset tak berwujud dimanfaatkan pada kegiatan operasional untuk memproduksi produk dan jasa. Aset ini juga dapat disewakan pada pihak lain dan dapat digunakan untuk tujuan administratif. Belkaoui (2003) menjelaskan bahwa praktek akuntansi konservatif berfokus pada penanaman modal instansi dalam modal intelektual. Modal intelektual tersebut dihasilkan dari kenaikan selisih antara nilai buku serta nilai pasar dan dilaporkan pada pelaporan finansial. Apabila nilai pasarnya efisien, hal ini mengindikasikan bahwa aset intelektual yang tinggi memberikan dampak atas kenaikan nilai instansi. Modal intelektual yang lebih besar akan mendorong investor untuk menghasilkan nilai yang tinggi atas instansi (Yuniasih et al. 2010).

Modal intelektual dimiliki oleh organisasi dengan pengetahuan serta keunikan pada sumber daya sehingga menjadikan organisasi mampu beradaptasi dengan baik (Purnomosidhi 2006). Pengungkapan modal intelektual merupakan aspek utama yang 
wajib dilaksanakan agar instansi memiliki kemampuan untuk menunjukkan eksistensi dalam menghadapi kompetitor. Pengungkapan modal intelektual menunjukkan kinerja perusahaan yang positif dan memberikan banyak keuntungan bagi perusahaan. Neysi et al. (2012) menjabarkan bahwa pengungkapan modal pengetahuan memberikan beberapa keuntungan diantaranya untuk meningkatkan transparansi perusahaan, meningkatkan kepercayaan stakeholders, dan memperkuat tercapainya tujuan jangka panjang perusahaan.

Beberapa perusahaan di Indonesia belum melakukan pengungkapan modal intelektual yang dimiliki dala laporan keuangan. Kamath (2014) menyatakan bahwa perusahaan sering kali tidak melaporkan modal intelektual yang dimiliki secara berkelanjutan. Hal tersebut ditimbulkan karena ketiadaan landasan yang baku terkait pengungkapan modal intelektual pada laporan keuangan. Kebutuhan stakeholder terkait wawasan mengenai pengungkapan modal intelektual diperlukan agar memaksimalkan informasi yang diterima sebagai bahan pengambilan keputusan. Tujuan dari riset ini guna memahami peranan pengungkapan modal pengetahuan, faktor penghambat dalam pengungkapannya, serta memahami pedoman yang dapat digunakan untuk pengungkapan modal intelektual bagi perusahaan.

\section{KAJIAN LITERATUR}

Berdasarkan Resourced Based Theory, instansi akan menimbulkan kinerja keuangan yang baik dan menjadi unggul dalam menghadapi kompetitor apabila memiliki strategi dalam mengontrol serta menggunakan aset strategis, baik aset fisik maupun non-fisik. Belkaoui (2003) menjelaskan bahwa strategi yang mampu mengoptimalkan sistem kerja instansi yakni mengkombinasikan aset fisik dan aset non-fisik. Upaya memaksimalkan penggunaan aset yang dimiliki oleh perusahaan diharapkan dapat memaksimalkan efektivitas dan efisiensi penggunaan sumber daya untuk mencapai output yang diharapkan.

Misi utama ekonomi dengan basis ilmu yakni mampu menhasilkan sebuah nilai lebih bagi setiap aktivitasnya. Dalam mewujudkan nilai tambah pada suatu perusahaan diperlukan ukuran yang tepat terkait modal yang dimiliki, baik potensi fisik berupa aset keuangan maupun potensi intelektual (Widarjo 2011). Potensi intelektual perusahaan dapat digambarkan dengan wawasan dan kemampuan karyawan dalam memaksimalkan kinerjanya. Resourced Based Theory adalah sebuah pola pikir yang dikembangkan lewat konsep managerial strategic serta kelebihan kompetitif instansi yang mempercayai bahwa tujuan instansi dapat tercapai jika mempunyai aset yang baik. Pendekatan ini memberikan pandangan bahwa optimalisasi aset yang suatu instansi miliki, termasuk aset tidak berwujud, akan berkontribusi pada peningkatan nilai perusahaan.

Pengungkapan merupakan bagian integral dalam pelaporan keuangan yang memiliki peran sangat penting dalam penyajian informasi akuntansi sebagai akibat adanya kondisi ketidakpastian pasar. Selain itu, stakeholders membutuhkan informasi relevan dan reliable yang tercermin dalam pengungkapan laporan keuangan. Pengungkapan berarti menyediakan informasi dalam laporan keuangan dan menjelaskan bagaimana implementasinya. Pengungkapan tidak meliputi pernyataan publik maupun pribadi yang diterbitkan oleh pihak pengelola dan data yang disediakan di luar laporan finansial.

Saat ini, penelitian mengenai pengungkapan modal intelektual banyak berkonsentrasi pada voluntary disclosure yang bersumber pada laporan tahunan 
(Dumay dan Guthrie 2017). Schaper et al. (2017) menjelaskan bahwa pengungkapan adalah sebuah tindakan menyingkapkan atau memberitahukan seluruh informasi, baik itu informasi baru maupun informasi bersifat rahasia yang relevan dengan sebuah perusahaan yang memiliki dampak pada proses pengambilan keputusan investasi. Pada umumnya, pengungkapan berhubungan dengan penyajian informasi secara sukarela. Pengungkapan berbeda dengan pelaporan. Pelaporan merupakan proses menghasilkan sebuah laporan yang mengomunikasikan kondisi keuangan kepada stakeholders pada suatu periode tertentu (Schaper et al. 2017). Dumay dan Guthrie (2017) memperkenalkan cara baru dalam mengukur pengungkapan modal intelektual yaitu secara tidak disengaja (involuntary disclosure). Pengungkapan ini merupakan informasi modal intelektual yang secara tidak sengaja diungkapkan oleh stakeholders dan pihak eksternal tentang kondisi perusahaan.

Chandra (2021) menyatakan bahwa istilah modal intelektual bukan sebuah konsep yang baru, namun belum terdapat pengertian yang bisa dipahami oleh khalayak umum. Bhasin (2011) menyatakan bahwa para akuntan, pelaku bisnis, dan pembuat kebijakan masih mencoba mencari kesepakatan mengenai konsep dan aplikasi modal intelektual sehingga definisi mengenai modal intelektual masih bervariasi. Secara umum, modal intelektual adalah suatu aktiva yang tidak mempunyai bentuk fisik seperti aset berbasis informasi yang berguna untuk memperbaiki sistem kerja instansi agar siap menghadapi persaingan dengan kompetitor. Modal intelektual bukan hanya berwujud goodwill dan hak paten yang umumnya dicatat dalam laporan posisi keuangan. Potensi yang dimiliki perusahaan berupa kompetensi karyawan, penciptaan inovasi, perkembangan sistem teknologi dan informasi, hubungan baik dengan pelanggan serta stakeholders merupakan bagian dari modal intelektual.

Kamath (2014) mendefenisikan modal intelektual sebagai segala kreasi dan ciptaan yang dihasilkan dari pikiran manusia. Sawarjuwono dan Kadir (2003) menjelaskan bahwa modal intelektual merupakan keseluruhan item yang ditimbulkan oleh aspek penentu suatu instansi yang berhubungan dengan teknologi serta ilmu sehingga mampu menghasilkan poin tambah. Seluruh aset yang suatu instansi miliki menghasilkan dampak yang signifikan pada peningkatan nilai tambah bagi stakeholders dan kemampuan perusahaan dalam persaingan usaha (Widarjo 2011). Investor akan menaruh minat pada instansi dengan modal intelektual yang tinggi. Nilai yang diberikan oleh investor akan tergambarkan pada harga saham instansi terkait (Chen et al. 2005).

Karakteristik modal intelektual dalam sebuah perusahaan terbagi atas tiga hal, yaitu non rivalrous, increasing return, dan not additive (Sangkala. 2006). Aset intelektual bisa dipergunakan dengan berkesinambungan oleh beragam pengguna, di lingkungan yang berbeda, di waktu yang sama. Sumber daya intelektual juga dapat menaikkan profit dari setiap penanaman modal yang dilaksanakan. Sesuatu dapat dikatakan sebagai sumber daya intelektual apabila mampu menciptakan nilai yang meningkat secara berkelanjutan, tanpa adanya pengurangan unsur pokok dari aset terkait. Sumber daya intelektual merupakan co-dependent dalam penciptaan suatu nilai.

Modal intelektual dapat digolongkan menjadi tiga elemen, diantaranya organizational capital, relational capital, dan human capital. Berikut adalah tabel yang menjelaskan komponen modal intelektual: 


\section{Tabel 1. Komponen Modal Intelektual}

\begin{tabular}{|l|l|l|}
\hline \multicolumn{1}{|c|}{ Organizational Capital } & \multicolumn{1}{|c|}{ Relational Capital } & \multicolumn{1}{c|}{ Human Capital } \\
\hline Intelectual Property & - Brand & • Know-how \\
- Paten & - Konsumen & • Pendidikan \\
- Copyrights & - Loyalitas konsumen & - Vocational qualification \\
- Design rights & - Nama perusahaan & - Pekerjaan dihubungkan \\
- Trade secrets & - Backlog orders & dengan pengetahuan \\
- Trademarks & - Jaringan distribusi & - Penilaian psychometric \\
- Service marks & - Kolaborasi bisnis & - Pekerjaan dihubungkan \\
Infrastructure Assets & - Kesepakatan lisensi & dengan kompetensi \\
- Filosofi manajemen & - Kontrak-kontrak yang & - Semangat entrepreneurial, \\
- Budaya perusahaan & mendukung & jiwa inovatif, kemampuan \\
- Sistem informasi & - Kesepakatan franchise & proaktif dan reaktif, \\
- Sistem jaringan & & kemampuan untuk \\
- Hubungan keuangan & & berubah \\
\hline
\end{tabular}

Sumber: Sawarjuwono dan Kadir (2003)

Human capital berkaitan dengan wawasan dan kompetensi tenaga kerja dalam menghasilkan lebih banyak poin tambahan untuk instansi. Organizational capital meliputi seluruh pengetahuan terkait asset infrastruktur, dan hak milik intelektual dari sebuah perusahaan yang keberadaannya mendukung human capital untuk menjalankan fungsi yang telah ditetapkan oleh manajemen tingkat atas. Relational capital mencakup seluruh nilai yang berhubungan dengan pelanggan dan pemasok, seperti networking, kontrak, dan perjanjian antara perusahaan dengan mitra.

\section{METODE PENELITIAN}

Metode yang dimanfaatkan pada riset ini merupakan metode kepustakaan yang menggunakan literatur sebagai objek penelitian. Chandra (2021) menyatakan bahwa metode ini sesuai digunakan untuk penelitian terkait modal intelektual di Indonesia karena masih sedikitnya perusahaan yang menerapkannya. Sumber data dalam penelitian diperoleh dari sumber pustaka berupa karya ilmiah, buku referensi, artikel ilmiah, dan sumber lain yang relevan. Informasi yang didapatkan akan dianalisa dengan memanfaatkan metode content analysis. Metode yang digunakan ini mampu memberikan temuan yang bisa dimanfaatkan menjadi landasan untuk menjawab pertanyaan pada riset ini.

\section{HASIL PENELITIAN DAN PEMBAHASAN}

Perlakuan akuntansi untuk modal intelektual merupakan problem untuk pelaku akuntansi (Sawarjuwono dan Kadir 2003). Manajemen perusahaan masih berupaya mengembangkan banyak konsep dan melakukan penilaian untuk menentukan pengukuran modal intelektual yang sesuai. Perusahaan berupaya melakukan penelitian dan pengembangan konsep pengukuran modal intelektual untuk membantu merancang strategi, menilai implementasi suatu strategi, menolong pemutusan kebijakan terkait diversifikasi serta perluasan, serta menjadi landasan dalam penentuan kompensasi. Pengukuran modal intelektual yang sesuai juga membantu perusahaan untuk mengkomunikasikan hasil pengukuran yang relevan kepada pihak eksternal. 
Secara umum, modal intelektual bisa ditinjau memanfaatkan cara yang biasa dikenal dengan Value Added Intellectual Capital (VAIC). Metode ini diciptakan oleh Pulic pada tahun 1997 dengan tujuan untuk menghasilkan pengetahuan mengenai value creation efficiency dari aktiva fisik maupun non-fisik yang suatu instansi miliki. Cara ini melakukan pengukuran atas level efektivitas capital employed serta intellectual capital saat menghasilkan nilai yang dilandasi oleh tiga aspek utama, yakni structural capital, capital employed serta human capital.

Penilaian modal intelektual diawali dengan kapabilitas suatu instansi dalam menghasilkan Value Added (VA). VA yang dinilai dengan mengurangi output dengan input adalah tolak ukur yang paling ideal untuk mengevaluasi kesuksesan suatu usaha serta mampu menggambarkan kapabilitas instansi pada value creation. Penghasilan serta semua produk yang diperdagangkan di pasar merupakan output, sementara semua beban yang dimanfaatkan pada proses mendapatkan penghasilan merupakan input.

Ulum (2013) menjelaskan bahwa ada tiga komponen penentu dalam pengukuran modal intelektual dengan menggunakan VAIC. Komponen pertama adalah Value Added Capital Employed (VACA). VACA adalah parameter untuk poin tambah yang dibentuk oleh suatu unit dari physical capital. Perbandingan ini menggambarkan kontribusi yang dihasilkan dari setiap unit pada capital employed atas nilai tambah instansi. VACA mengilustrasikan jumlah VA yang diperoleh dari modal instansi yang dimanfaatkan.

Komponen kedua adalah Value Added Human Capital (VAHU). VAHU memperlihatkan relasi antara nilai tambah dengan human capital. VAHU mengindikasikan jumlah VA dapat diperoleh melalui modal yang dikeluarkan untuk karyawan. Relasi antara VA dan HC enggambarkan kapabilitas dari human capital dalam menghasilkan nilai di suatu instansi. Komponen ketiga adalah Structural Capital Value Added (STVA). STVA memberikan gambaran terkait sumbangsih structural capital pada penciptaan VA perusahaan. STVA meninjau nilai structural capital yang diperlukan untuk menghasilkan 1 rupiah dari VA dan adalah penentu kesuksesan SC untuk menciptakan nilai. SC tidak berperan sebagai tolak ukur yang tidak terikat seperti HC, SC tidak terikat value creation. Hal ini menunjukkan bahwa sumbangsih HC yang tinggi pada value creation akan memperkecil sumbangsih SC pada hal terkait

Berdasarkan konsep pengukuran modal intelektual yang ada, Sawarjuwono dan Kadir (2003) menyatakan bahwa tidak ada satupun metode yang ditawarkan dapat memenuhi semua tujuan yang ingin diperoleh. Hal ini menyebabkan pentingnya pemilihan metode pengukuran yang sesuai dengan kondisi dan keperluan perusahaan.

Modal intelektual mampu memberikan informasi relevan dalam pengambilan keputusan investasi sehingga investor dapat memberikan penghargaan lebih kepada perusahaan yang mampu mengelola modal intelektual yang dimiliki secara optimal. Dalam laporan keuangan, maupun laporan tahunan perusahaan, laporan tersebut menyajikan berbagai hal penting dan relevan mengenai kondisi perusahaan dalam suatu periode tertentu. Suatu informasi dapat dikatakan relevan jika dapat berpengaruh terhadap proses pengambilan keputusan, ada atau tidaknya informasi tersebut akan menghasilkan keputusan yang berbeda (Kieso 2018).

Implementasi modal intelektual pada perusahaan mampu meningkatkan kepercayaan investor terhadap perusahaan. Hal ini akan berimbas pada peningkatan investasi bagi perusahaan sehingga mampu meningkatkan profitabilitas dan nilai perusahaan. Pengungkapan modal intelektual akan membantu terciptanya peningkatan 
kinerja keuangan yang merupakan salah satu faktor dalam menunjukkan efektivitas, efisiensi, dan optimalisasi suatu perusahaan dalam mencapai tujuan yang diinginkan. Kieso (2018) menyatakan bahwa dalam mengambil keputusan untuk menyediakan sumber daya bagi perusahaan, para pemilik sumber daya membutuhkan informasi mengenai kinerja dan status keuangan perusahaan. Informasi tersebut bisa didapatkan dari laporan keuangan. Elemen dasar yang memiliki keterkaitan langsung dengan proses pengukuran kinerja dan status keuangan perusahaan adalah asset, liabilities, equity, income, dan expenses.

Modal intelektual berkaitan dengan karakteristik dasar aset. Pengeluaran perusahaan berkaitan dengan komponen utama modal intelektual yang dapat memberikan manfaat ekonomis bagi perusahaan di masa mendatang. Kepemilikan modal intelektual mampu menunjang tercapainya tujuan perusahaan sehingga perusahaan dapat bertahan bahkan berkelanjutan. Potensi yang ada dalam komponen utama modal intelektual adalah aset milik perusahaan yang dapat dikendalikan oleh perusahaan sepenuhnya (Sawarjuwono dan Kadir 2003). Selain bagi para investor, informasi terkait modal intelektual juga menjadi suatu hal yang penting bagi pemangku kepentingan lainnya, seperti pelanggan. Ulum et al. (2019) menyatakan bahwa secara spesifik dalam penelitiannya terhadap berbagai universitas di Indonesia menggambarkan bahwa pengungkapan modal intelektual mempunyai dampak positif terhadap minat calon mahasiswa supaya mendaftar di suatu universitas. Informasi modal intelektual juga menjadi fokus para calon mahasiswa dalam menentukan universitas pilihan.

Solechan (2017) menemukan bahwa modal intelektual berpengaruh positif terhadap kinerja keuangan perusahaan. Hal ini mendukung penelitian Chen et al. (2005) yang menyatakan bahwa modal intelektual berpengaruh signifikan terhadap kinerja keuangan dan nilai pasar perusahaan. Penelitian tersebut mengindikasikan bahwa para investor menilai perusahaan lebih tinggi dengan kepemilikan modal intelektual yang lebih tinggi. Investor akan membayar lebih tinggi pada saham perusahaan yang memiliki sumber daya intelektual lebih tinggi. Chandra dan Djajadikerta (2017) menemukan bukti empiris bahwa modal intelektual berpengaruh signifikan terhadap nilai perusahaan. Hal ini mendukung hasil penelitian Nuryaman (2015) yang membuktikan bahwa modal intelektual berpengaruh positif terhadap nilai perusahaan.

Adanya tantangan maupun kesulitan dalam praktik pengungkapan modal intelektual sebagai aset menjadikan perusahaan menggolongkan pengeluaran untuk modal intelektual sebagai beban. Kieso (2018) mendefenisikan beban sebagai depresiasi manfaat ekonomis sepanjang periode akuntansi dalam bentuk aset yang dikorbankan atau penyusutan asset atas terjadinya kewajiban yang mengakibatkan penurunan modal selain berhubungan dengan pembagian kepada penyedia modal. Berdasarkan arti tersebut, pengeluaran-pengeluaran sehubungan dengan modal intelektual tidak tepat jika dicatat sebagai beban karena memiliki kemampuan untuk memberikan keuntungan ekonomis di masa mendatang. Modal intelektual tepatnya diungkapkan dalam laporan keuangan sebagai aset dari pada beban karena memiliki karakteristik yang lebih dekat dengan aset. Chandra (2021) mengatakan bahwa karena pengungkapan modal intelektual sifatnya sukarela itu sebabnya laporan tahunan (annual report) perusahaan cenderung berfokus pada kinerja keuangan saja. Mayoritas perusahaan lebih cenderung melaporkan kinerja modal intelektual sebagai appendix dan beberapa lainnya melaporkan dalam laporan yang terpisah. Anggraini (2013) 
menemukan bukti bahwa perusahaan tidak berusaha melakukan pengukuran modal intelektual dalam satuan mata uang sehingga tidak dilakukan pengungkapan modal intelektual dalam satuan mata uang.

Sawarjuwono dan Kadir (2003) mengatakan bahwa walaupun mempunyai karakteristik aset akan tetapi modal intelektual belum bisa diperlakukan seperti aset pada biasanya yang diukur dan dapat disajikan dalam laporan keuangan karena mengalami kesulitan pengukuran terhadap modal intelektual. Modal intelektual dapat merepresentasikan gambaran mengenai penciptaan nilai dalam perusahaan akan tetapi praktik akuntansi tidak memiliki alat untuk mengidentifikasikan, mengukur, dan mengungkapkan modal intelektual dalam laporan tahunan perusahaan. Hal tersebut sejalan dengan penelitian yang dilakukan oleh Castilla Polo dan Vasquez (2016) yang menemukan bukti bahwa ada banyak hal yang menjadi alasan langsung perusahaan menolak untuk melakukan praktik pengungkapan modal intelektual ialah kerumitan, identifikasi, dan pengukuran.

Chandra (2021) mengatakan bahwa perusahaan bisa menyajikan kepemilikan modal intelektual dalam sebuah laporan terpisah mengenai modal intelektual yang disebut intellectual capital statement. Sawarjuwono dan Kadir (2003) mengemukakan bahwa intellectual capital statement merupakan sebuah bentuk laporan yang kompleks dengan mengombinasikan angka, narasi dari pengetahuan yang dimiliki oleh perusahaan dan visualisasi yang bisa berupa sketsa yang memberikan ilustrasi kerja modal intelektual. Adapun laporan modal intelektual dibagi dari tiga dimensi dasar, yaitu dimensi pertama ialah adanya beberapa bentuk knowledge narrative yang menjelaskan kemampuan perusahaan dan cara perusahaan supaya dapat melakukan kegiataan maupun aktivitas operasional dengan baik. Dimensi kedua yaitu berkaitan dengan tantangan dan hambatan yang dialami oleh manajemen berkenaan dengan pengelolaan pengetahuan, usaha manajemen perusahaan untuk mengembangkan pengetahuan dan kondisi pengetahuan yang dimiliki oleh perusahaan. Dimensi ketiga yakni adanya gabungan atau kombinasi angka, visualisasi, dan narasi yang menggambarkan pengembangan sumber pengetahuan yang ada pada perusahaan.

Dalam penyusunan laporan keuangan perusahaan, setiap entitas wajib mengikuti aturan dan ketentuan yang ada dalam pedoman penyusunan laporan keuangan, yaitu Standar Akuntansi Keuangan (SAK). Sementara itu pedoman tentang penyusunan modal intelektual di Indonesia tercantum secara implisit dalam Pernyataan Standar Akuntansi Keuangan (PSAK) 19 yang membahas tentang aset tak berwujud termasuk modal intelektual. Aset tak bewujud dicatat senilai jumlah tercatat aset yakni jumlah aset yang diakui dalam laporan neraca setelah dikurangi dengan akumulasi penyusutan atau amortisasi dan akumulasi rugi penurunan nilai. Aset tak berwujud seharusnya dapat diidentifikasikan, dikendalikan, dan harus memiliki manfaat ataupun kegunaan dimasa mendatang. Dalam PSAK 19 mengatur tentang salah satu komponen modal intelektual yakni modal manusia (human capital). Perusahaan dapat mempunyai sumber daya manusia atau tenaga kerja yang terampil dan perusahaan juga melaksanakan berbagai pelatihan (training) yang memiliki kegunaan ekonomis di masa mendatang. Dalam hal sumber daya manusia atau tenaga kerja, sulit untuk perusahaan untuk mengklasifikasikan sumber daya manusia sebagai aset karena belum tentu perusahaan bisa mengontrol manfaat ekonomis di masa yang akan datang dari talenta yang dimiliki sumber daya manusia maupun yang timbul dari pelatihan yang dilakukan oleh perusahaan. 
Secara spesifik, PSAK 19 menguraikan tentang hal-hal mengenai aset tak berwujud yang dianjurkan untuk dilakukan praktik pengungkapan modal intelektual yaitu:

- Deskripsi tentang aset tak berwujud yang telah diamortisasikan seluruhnya tapi masih digunakan

- Deskripsi tentang aset tak berwujud signifikan yang dikendalikan entitas namun tidak diakui sebagai aset karena tidak memenuhi kriteria pengakuan dalam pernyataan ini atau karena aset tersebut diperoleh atau dihasilkan sebelum PSAK 19 Aset tak berwujud efektif diberlakukan.

PSAK 19 mengindikasikan bahwa tidak semua modal intelektual dapat diungkapkan dalam laporan keuangan perusahaan. Anggraini (2013) melakukan pemetaan mengenai pengungkapan modal intelektual pada perusahaan perbankan yang terdaftar di Bursa Efek Indonesia menemukan bahwa tidak terdapat kerangka yang sistematis dan konsisten dalam pengungkapan modal intelektual namun dapat ditemukan adanya pola-pola khusus tertentu. Pengungkapan modal intelektual sebagian besar dilakukan dalam laporan tahunan perusahaan dalam bentuk narasi nonnumerik dan bersifat informatif. Pengungkapan modal intelektual tersebut merupakan deskriptif atas kejadian-kejadian yang telah dialami oleh perusahaan.

\section{SIMPULAN, KETERBATASAN, DAN SARAN}

Kesimpulan dalam penelitian ini ialah praktik pengungkapan modal intelektual seharusnya dilakukan karena merupakan sebuah informasi relevan yang harus diketahui oleh para pemakai laporan keuangan dalam menilai perusahaan untuk proses pengambilan berbagai keputusan dan dapat membantu perusahaan melakukan pengelolaan sumber daya dengan lebih efektif dan efisien. Walaupun pengungkapan modal intelektual itu penting, akan tetapi pada praktinya mengalami berbagai tantangan dan hambatan yakni tidak adanya alat untuk mengidentifikasikan, mengukur, dan mengungkapkan modal intelektual sehingga perusahaan kerap tidak mengungkapkan modal intelektual secara berkelanjutan. Pada dasarnya pedoman mengenai modal intelektual di Indonesia tercantum secara implisit dalam PSAK 19.

Peneliti menyarakan agar penelitian selanjutnya meneliti tentang praktik nyata pengungkapan modal intelektual sehingga bisa mendapatkan gambaran nyata mengenai pengungkapan modal intelektual yang selanjutnya dapat menjadi bahan referensi dalam penyusunan pedoman baku tentang modal intelektual dan wawasan bagi seluruh pihak yang berkepentingan. Kemudian untuk perusahaan sebaiknya melakukan praktik modal intelektual secara berkelanjutan dalam laporan yang dipublikasikan supaya informasi tentang modal intelektual dapat diakses oleh para pemangku kepentingan perusahaan sehingga tidak terjadi kekeliruan dalam proses pengambilan keputusan yang berkaitan dengan informasi perusahaan. 


\section{DAFTAR PUSTAKA}

Anggraini, Y. D. 2013. Pemetaan Pola Pengungkapan Intellectual Capital PerusahaanPerusahaan Perbankan yang Terdaftar pada Bursa Efek Indonesia Periode 2011. Calyptra: Jurnal Ilmiah Mahasiswa Universitas Surabaya 2 (2).

Belkaoui, A. 2003. Intellectual capital and firm performance of US multinational firms: A study of the resource based and stakeholder views. Journal of Intellectual Capital.

Bhasin, M. L. 2011. Intellectual Capital Reporting Study of IT-Sector Corporations in India. Australian Journal of Business and Management Research 1 (1):16-28.

Castilla Polo, F., dan G. Vasquez. 2016. The Main Topics of Research on Disclosure of Intangible Assets: A Critical Review. Accounting, Auditing \& Accountability Journal 29 (2):323-356.

Chandra, H. 2021. Pengungkapan Modal Intelektual. Jurnal Akuntansi 1 (13):1-11.

Chandra, H., dan H. Djajadikerta. 2017. Pengaruh intellectual capital, profitabilitas, dan leverage terhadap nilai perusahaan pada perusahaan sektor properti, real estate, dan konstruksi bangunan yang terdaftar di bursa efek indonesia. Ultimaccounting: Jurnal Ilmu Akuntansi 9 (2):1-14.

Chen, M. C., S. J. Cheng, dan Y. Hwang. 2005. An Empirical Investigation of The Relationship Between Intellectual Capital and Firm's Market Value and Financial Performance. Journal of Intellectual Capital 6 (2):159-176.

Dumay, J., dan J. Guthrie. 2017. Involuntary Disclosure of Intellectual Capital: Is It Relevant? Journal of Intellectual Capital 18 (1):29-44.

Festa, G., M. Rossi, A. Kolte, dan L. Marinelli. 2021. The Contribution of Intellectual Capital to Financial Stability in Indian Pharmaceutical Companies. Journal of Intellectual Capital 22 (2):128-148.

Garanina, T., dan J. Dumay. 2017. Forward-Looking Intellectual Capital Disclosure in IPOs: Implications for Intellectual Capital and Integrated Reporting. Journal of Intellectual Capital 18 (1):128-148.

Guthrie, J., dan R. Petty. 2000. Intellectual Capital: Australian Annual Reporting Practices. Journal of Intellectual Capital 1 (3):241-251.

Kamath, G. B. 2014. A Theoretical Framework for Intellectual Capital Disclosure. Pacific Business Review International 6 (8):50-54.

Kieso, D. E., Weygandt, J.J.,\& Warfield, T.D. 2018. Intermediate Accounting: IFRS Edition Third ed: John Wiley \& Sons.

Lestari, B. D., dan A. W. Suryani. 2020. Firm's Value Exploration: The Impact Of Intellectual Capital and Net Working Capital. Jurnal Dinamika Akuntansi 12 (2):152-164.

Neysi, S. H., S. Mazraeh, dan Z. Mousavi. 2012. The Importance of Intellectual Capital Disclosure. International Journal of Business and Social Sciences 3 (15):307310.

Nuryaman, N. 2015. The influence of intellectual capital on the firm's value with the financial performance as intervening variable. Procedia-Social and Behavioral Sciences:292-298.

Oktavianti, Heni, dan Wahidahwati. 2014. Faktor-faktor yang mempengaruhi pengungkapan intellectual capital. Journal Ilmu \& Riset Akuntansi 3 (1):4864. 
Purnomosidhi, B. 2006. Praktik Pengungkapan Modal Intelektual pada Perusahaan Publik di BEJ. The Indonesian Journal of Accounting Research (IJAR) 9 (1).

Sangkala. 2006. Intellectual Capital Management-Strategi Baru Membangun Daya Saing Perusahaan. Jakarta: YAPENSI.

Sawarjuwono, T., dan A. P. Kadir. 2003. Intellectual Capital: Perlakuan, Pengukuran, dan Pelaporan. Jurnal Akuntansi \& Keuangan 5 (1):35-57.

Schaper, S., C. Nielsen, dan R. Roslender. 2017. Moving from Irrelevant Intellectual Capital (IC) Reporting to Value-Relevant IC Disclosures. Journal of Intellectual Capital 18 (1):81-101.

Secundo, G., P. Del Vecchio, J. Dumay, dan G. Passiante. 2017. Intellectual Capital in the Age of Big Data: Establishing a Research Agenda. Journal of Intellectual Capital 18 (2):242-261.

Singh, I., dan J. L. W. Mitchell Van der Zahn. 2008. Determinants of intellectual capital disclosure in prospectuses of initial public offerings. Accounting and Business research 38 (5):409-431.

Solechan, A. 2017. Pengaruh Efisiensi Modal Intelektual Terhadap Kinerja Keuangan Di Indonesia. Jurnal Kajian Akuntansi 1 (1):87-100.

Ulum, I. 2013. Model pengukuran kinerja intellectual capital dengan iB-VAIC di perbankan syariah. INFERENSI: Jurnal Penelitian Sosial Keagamaan 7 (1):185-206.

Ulum, I., R. R. Harviana, S. Zubaidah, dan A. W. Jati. 2019. Intellectual Capital Disclosure and Prospective Student Interest: An Indonesian Perspectives. Cogent Business \& Management 6 (1):1-13.

Widarjo, W. 2011. Pengaruh modal intelektual dan pengungkapan modal intelektual pada nilai perusahaan yang melakukan Initial Public Offering. Jurnal Akuntansi dan Keuangan Indonesia 8 (2):157-170.

Yuniasih, N. W., D. G. Wirama, dan I. D. N. Badera. 2010. Eksplorasi Kinerja Pasar Perusahaan: Kajian Berdasarkan Modal Intelektual (Studi Empiris pada Perusahaan Keuangan Yang Terdaftar di Bursa Efek Indonesia). Simposium Nasional Akuntansi XIII Purwokerto:1-29. 